Click www.researchjournal.co.in/online/subdetail.html to purchase.

INTERNATIONAL JOURNAL OF PLANT PROTECTION

- ISSN-0974-2670 | Visit us : www.researchjournal.co.in

\title{
Association of biochemical constituents with anthracnose resistance in chilli
}

\author{
K. Arjun ${ }^{1}$, T. Arumugam*2, M. Karthikeyan ${ }^{1}$, H. Usha Nandhini Devi ${ }^{1}$ and S. Mohankumar ${ }^{3}$
}

${ }^{1}$ Department of Vegetable Science, Horticultural College and Research Institute, Tamil Nadu Agricultural University, Coimbatore (T.N.) India

${ }^{2}$ Horticultural College and Research Institute, Tamil Nadu Agricultural University, Periyakulam (T.N.) India ${ }^{3}$ Centre for Plant Molecular Biology and Biotechnology, Tamil Nadu Agricultural University, Coimbatore (T.N.) India

\section{ARITCLE INFO}

Received : 15.06 .2020

Revised : 01.07 .2020

Accepted : 12.07 .2020

\section{KEY WORDS :}

Chilli, Colletotrichum species, Fourier transform near-infrared spectrophotometer, Capsaicin

*Corresponding author:

Email : tarumugam64@gmail.com

\begin{abstract}
Colletotrichum species is considered as amajor fungal pathogen that can cause economic damage in commercial chilli production because of its ability to infect fruits both at pre- and post-harvest stages. Results obtained from the Fourier transform near-infrared spectrophotometer in chilli genotypes indicated that, there is a significant difference among the chilli genotypes for both quantitative and qualitative traits. Furthermore, capsaicin and oleoresin contents have a significant linear relationship with resistance to anthracnose at red fruit stage. Incidentally, chilli genotypes that are moderately resistant to anthracnose were significantly superior in capsaicin and oleoresin contents and fruit yield. Hence, capsaicin and oleoresin content can be used as an indirect method to predict anthracnose resistance in chilli breeding.
\end{abstract}

How to view point the article : Arjun, K., Arumugam, T., Karthikeyan, M., Usha Nandhini, Devi, H. and Mohankumar, S. (2020). Association of biochemical constituents with anthracnose resistance in chilli. Internat. J. Plant Protec., 13(2) : 131-137, DOI : 10.15740/HAS/IJPP/13.2/ 131-137, Copyright@2020: Hind Agri-Horticultural Society. 